Revistade
Economild
Contemporâned

\title{
A CASE FOR INDUSTRIAL POLICY? FORECAST RESULTS FROM A DISAGGREGATED BOP-CONSTRAINED GROWTH MODEL FOR BRAZILIAN ECONOMY (2016-2025)
}

\author{
Cryslãine Flavia da Silva Rodrigues ${ }^{a}$ \\ André Luís Cabral de Lourenço ${ }^{b}$
}

aph.D student in Development Economics by the Postgraduate Program in Economics, Federal University of Rio Grande do Sul (UFRGS). Porto Alegre, RS, Brazil. ORCID: https://orcid.org/0000-0002-7995-2172.

'Professor at the Economics Department, Federal University of Rio Grande do Norte (UFRN). Natal, RN, Brazil. ORCID: https://orcid.org/0000-0001-6374-7302.

Received on 3 April 2019

Accepted on 5 December 2019

\begin{abstract}
The article aimed to forecast the Brazilian economy's growth potential in the 2016-2025 period, assuming the absence of changes in industrial policy. It is based on a formal growth model constrained by the balance of payments (BOP) developed by the authors and disaggregated into three sectors (farming, industry, and services). All its parameters were econometrically estimated, including those of the world economy relevant to the Brazilian economy's performance. Assuming that the current macroeconomic management "tripod" was maintained in the country, the basic interest rate and exchange rate policy were calibrated to generate the maximum growth rate allowed by the external constraint compatible with the maintenance of inflation in target each year. Forecasts were also made about the performance of the three sectors' key variables, resulting from such calibration. Forecasted potential GDP and productivity growth were low (even by recent historical standards) and decreasing over time, with slower growth in the industrial sector than in other ones. The results revealed the critical importance of the
\end{abstract}

Correspondência para: Cryslãine Flavia da Silva Rodrigues

Contato: crys-cg@hotmail.com

Todo o conteúdo deste periódico, salvo indicação em contrário, está licenciado sob os termos da Creative 
industrial sector for such performance, suggesting that an efficient industrial policy could significantly increase the Brazilian economy's growth potential.

KEYWORDS: macroeconomic simulation; economic growth; industry; Brazil. JEL CODES: E03; E17; O41. 


\section{UM CASO PARA POLÍTICA INDUSTRIAL? RESULTADOS DE PREVISÕES PARA A ECONOMIA BRASILEIRA (2016-2025) A PARTIR DE UM MODELO DESAGREGADO DE CRESCIMENTO RESTRINGIDO PELO BP}

RESUMO: O artigo teve como objetivo projetar o potencial de crescimento da economia brasileira no período 2016-2025, supondo a ausência de modificações na política industrial. Parte-se de um modelo formal de crescimento restringido pelo balanço de pagamentos (BP) desenvolvido pelos autores e desagregado em três setores (agropecuária, indústria e serviços). Todos seus parâmetros foram econometricamente estimados, inclusive os da economia mundial relevantes para o desempenho da economia brasileira. Pressuposta a manutenção do atual "tripé" de gestão macroeconômica vigente no país, calibrou-se a taxa de juros básica e a política cambial de modo a gerar a taxa máxima de crescimento permitida pela restrição externa compatível com a manutenção da inflação na meta a cada ano. Foram também geradas projeções acerca do desempenho das variáveis-chave dos três setores, decorrentes de tal calibragem. As projeções de crescimento do PIB potencial e da produtividade foram baixas (mesmo para padrões históricos recentes) e decrescentes no tempo, com crescimento mais lento no setor industrial do que nos demais setores. Os resultados revelaram a importância crítica do setor industrial para tal desempenho, sugerindo que uma política industrial eficiente poderia aumentar significativamente o potencial de crescimento da economia brasileira.

PALAVRAS-CHAVE: simulação macroeconômica; crescimento econômico; indústria; Brasil. 


\section{INTRODUCTION}

Since the mid-1980s, the participation of the Brazilian manufacturing industry in the national GDP started to present a major setback (from 32\% in 1986 to $13.2 \%$ in the year 2013, according to IPEADATA, 2014). Taking that into account several authors of the heterodox economic literature, have tried to explain the trend of instability and low growth of the Brazilian economy over the last decades. Within the framework of a controversial theoretical and empirical debate, explanations have been offered based not only on the significant slowdown and technological lag presented by the country's industrial sector but also based on the current management model of Brazilian macroeconomic policy, supported by the "tripod" inflation target, government's budget primary surpluses and floating exchange rate. Some authors, like Bonelli and Pessoa (2010) and Bonelli and Pinheiro (2012) defended that this process represents merely a natural convergence of the national industry to world's average. Others like Palma (2005), Dasgupta and Singh (2006), Bresser-Pereira and Marconi (2008), and Oreiro and Feijó (2010) argue that the Brazilian industry deceleration, otherwise represents a process of early and harmful de-industrialization for the Brazilian's economic growth, which is directly associated with the drastic change of the old regime of import substitution by another. Since the 1990s, this new one has combined rapid commercial and financial liberalization of the economy with macroeconomic policies that, in general, kept the real exchange rate exceptionally low (stimulating imports and discouraging exports) and, therefore, obstructed the transition of the country towards a more mature form of industrialization in terms of technological development and, consequently, in terms of exports.

Not neglecting the effects of Brazilian macroeconomic policy, Arend (2014) affirms that Brazil has been presenting an expressive process of early de-industrialization, which has clearly jeopardized its economic dynamism and has coincided with factors related to both the domestic and international dimension. According to him, regarding the domestic dimension, it coincides with the end of industrial policies, with commercial and financial liberalization and exchange rate overvaluation. As for the international dimension, it coincides with a new technological and industrial revolution, expressed in the emergence of the microelectronic paradigm.

In view of such debate, the present article aims to investigate the following question: given the current profile of the specialization pattern of the productive structure (characterized by the low participation of modern industries linked to the new technological frontier and, thus, to the production of high aggregated value products) and the country's commercial insertion (exports heavily concentrated in primary and/or low value-added products, and imports concentrated on higher value-added manufactured products), as well as the current model of macroeconomic policy 
management in Brazil, what is the potential growth of the Brazilian economy in a relatively long future period corresponding to the years 2016-2025? In order to support this study, we elaborated a formal projective macroeconomic model, built on the assumption of economic growth under external constraint, disaggregated into the farming, industry, and services sectors, and conditioned by the current management model of Brazilian macroeconomic policy.

This analysis aims to project the potential growth of the Brazilian economy and is relevant because it allows us to understand better and demonstrate the limiting mechanisms of such growth. And so, it allows investigating to some extent the negative aspects highlighted in the Brazilian deindustrialization debate, providing new subsidies to the discussion.

Our simulation period is still relevant because it allows us to some extent, counterfactualize with the economic crisis of 2015-2017. Although this occurred due to the fall in aggregate demand (and not to a balance of payment crisis), our simulations are consistent with the observed behavior of imports, which, according to IBGE (2017, p. 18), showed a decrease (-10.2\%) significantly higher than the reduction of GDP of the economy $(-3.5 \%)$ in the year 2016 , growing soon after at an expressive rate $(5 \%)$ in the year 2017, despite the still low growth of the Brazilian GDP (only 1\%) and the decline of $1,8 \%$ in gross fixed capital formation (which has a high degree of imported components). This behavior of imports (a significant drop in economic downturns and an accelerated growth even when the economy still shows signs of slow recovery) is quite typical of economies that present a high-income elasticity of demand for imports, which constitutes the Brazilian case and appears in evidence in our simulations.

That being said, this article is divided into four main sections, besides this introduction. Section 1 gives a brief description of the model used. In section 2, we present the estimated values of the main parameters of the model. Section 3 contains the main results obtained from the simulations, which allow evaluating the potential growth of the Brazilian economy in the period 2016-2025. Finally, concluding remarks are presented.

\section{A BRIEF EXPOSITION OF THE FORMAL MACROECONOMIC MODEL USED IN SIMULATIONS}

The formal macroeconomic model developed to support our simulations has 53 equations, most of which disaggregated into three productive sectors: farming, industry, and services. Therefore, given its extension, it should be emphasized that the purpose of this section is not to present the model in its entirety (which is the target of another paper yet to be published), but only to highlight its main characteristics, premises, and causal relations. 
In this sense, an important aspect of the model to be emphasized is that despite its extension, the model was intended to describe only the potential (and not the effective evolution) of the country's economic growth. In this way, it merely specifies the limit to which the aggregate demand management can act to accelerate growth. In other words, it does not model the growth of aggregate demand, which in our view determines the effective growth rate.

It should be noted too that by adopting the heterodox assumption that the balance of payments and installed capacity are the main constraints on the potential growth of an open economy, the construction of the model was directly inspired by Thirlwall (1979) and it's theoretical developments which appear in the following works: Araujo and Lima (2007), Lourenço et al. (2011), Bhering (2013), Amado and Dávila-Fernández (2014), Araujo (2011), and Ferrari, Freitas and Barbosa Filho (2013). Based on a Kaldorian approach to export-led growth - especially of industrial products -, Thirlwall (1979) formalized the following growth model. Unlike what happens in Kaldor's model, in Thirlwall's the balance of payments (BP) appears not as a condition of equilibrium in relation to the product level, but as a constraint to its growth:

$$
\begin{gathered}
g_{t}=\varepsilon\left(Z_{t}\right) / \pi \\
\text { ou } \\
g_{t} / Z_{t}=\varepsilon / \pi
\end{gathered}
$$

Through such a model, Thirlwall (1979) tells us that the growth rate of a country is directly proportional to the growth rate of all other countries $(Z)$ and the ratio of the income elasticities of demand for exports and imports ( $\varepsilon$ and $\pi$, respectively). This means that since countries have a limit on the supply of foreign exchange to meet their import needs, the external constraint on growth will be lower the higher the income elasticity ratio of foreign trade, that is, the higher the ratio $(\varepsilon / \pi)$. Thus, the economic policy recommendation that derives from such an equation (called "Thirlwall's law" in the literature) is that, in the long run, the only sure way to increase a country's growth rate, in line with the equilibrium of the balance of payments, is the realization of a structural change of the economy in order to increase $\varepsilon$ and/ or reduce $\pi$ (THIRLWALL, 2005).

While Thirlwall (1979) delivered an aggregate model for a sector that thus not capture the different income elasticities of demand for exports and imports presented by the different sectors that make up the productive structure of a country, Araujo and Lima (2007) aimed to develop a multisectoral growth model compatible with the hypothesis of growth restriction by the BP. In turn, Lourenço et al. (2011) and Bhering (2013) sought to incorporate the capital flow effect into a growth model restricted by BP, considering a priori the possibility of sustainable expansion of net 
external liabilities. Contrary to Thirlwall (1979), Amado and Dávila-Fernández (2014) rejected the validity of long-term purchasing power parity and sought to incorporate into the model the effect of terms of trade dynamics on long-term growth. Finally, also contrary to Thirlwall (1979), Araujo (2011) argues that permanent changes in the nominal exchange rate, as they can affect the export capacity of some sectors of the economy, have important impacts on a country's sectoral composition and, consequently, in its long-term growth rate. Similarly, Ferrari, Freitas and Barbosa Filho (2013) propose an external restriction model with endogenous elasticities, based on the fundamental hypothesis that managing the real exchange rate to a stable and competitive level can generate effects that transcend the adjustment of aggregate demand in short-term, changing the price and income elasticities of import and export demand, so as to modify the long-term relationship - verified in Thirlwall's seminal model - between the growth rate of domestic product and the growth rate of the world economy. Later we will highlight which the sustainability conditions suggested by these authors were included in our model.

In an attempt to make the simulations conditioned by the current management model of Brazilian macroeconomic policy, the aforementioned model was also directly inspired by the work of Lourenço and Roos (2015).

In methodological terms, the model was divided into three main parts. The first two parts of the model allow us to see in more detail the impact of the current pattern of productive specialization (reflected in the country's trade pattern) not only on the behavior of the economy's external assets and liabilities and on the determination of the nominal exchange rate (first part of the model), but mainly on determining the maximum economic growth rate allowed by the balance of payments (the second part of the model). Using these first two parts of the model, we believe we can contribute to the debate on the character of Brazil's deindustrialization, whether a negative or positive phenomenon from the point of view of Brazil's potential growth. The third part of the model (focusing on the process of price formation and inflation) helps us to visualize better how the current management model of the country's macroeconomic policy (centered on the objective of controlling inflation, and which limits the use of the exchange rate policy) can affect the potential growth of the industrial sector and the Brazilian economy. The option for a three-sector model may appear strange at first glance once it lies halfway between an aggregate model and a more disaggregated (and arguably preferable) one. However, at least at the first stage of this research, the three-sector model seems preferable to both extreme options. Indeed, an aggregated model will not be fit to treat the sectorial issue, and each additional sector imposes an exponentially increasing cost in terms of (time-consuming) parameter estimation. So, a three-sector model seems the minimal necessary to offer sectorial results at a 
manageable cost. Future research will be needed to find ways to increase disaggregation level without prohibitive costs. With respect to the first part of the model, it should be pointed out that it started directly from the traditional identities of National Accounts; and the variation of the nominal exchange rate, in line with Lourenço and Roos's (2015) model, constituted the element that, in the context of relatively free capital mobility apart the fixation of the average tax aliquot on financial transactions (IOF Imposto sobre Operações Financeiras, in Portuguese) - makes the desired path for international reserves compatible with the surpluses or deficits of the balance of payments (BP). The determination of the nominal exchange rate (e) was thus modeled:

$$
\frac{e_{t}}{e_{t+1}^{e}} \equiv \frac{R_{t}-R_{t-1}\left(1+\hat{e}_{R}\right)-B C T_{t}-\left(\Psi_{2, t}+f_{0}+f_{2} t\right) Y_{t}^{*}}{f_{1}\left[\frac{\left(1+i_{t}\right)}{\left(1+i_{t}^{*}\right)\left(1+I O F_{t}\right)\left(1+\rho_{t}^{*}\right)}+\frac{\left(1+\lambda_{t-1}\right)}{\left(1+\lambda_{t-1}^{*}\right)\left(1+\rho_{t}^{*}\right)}\right] Y_{t}^{*}}
$$

where $\mathrm{e}^{\mathrm{e}}$ is the expected nominal exchange rate; $\mathrm{R}$ refers to international reserves and BCT is the balance of current transactions, both in US\$; $\hat{e}_{R}$ is the average rate of change of the prices (in US\$) of international reserves; $\Psi_{2}$ is a random variable of zero value and normal distribution; $f_{0} f_{1}, f_{2}>0$ are parameters; $Y^{\star}$ is the level of world's GDP; $i$ is the domestic nominal interest rate (Selic); $\mathrm{i}^{*}$ is the external nominal interest rate; $\rho^{*}$ is the country risk; $\lambda$ e $\lambda^{\star}$ are, respectively, the rates of profit in Brazil and in the rest of the world. Considering the reserves policy chosen by the government and the inflationary impact of exchange rate depreciations, the external restriction manifests itself in two ways. First, in the existence of a limit to the sustainable external indebtedness, here defined in line with Lourenço et al. (2011), and, therefore, in the sense such a limit maintains the growth of the Net External Liabilities (NEL) equal to or less than the nominal GDP expansion rate of the "rest of the world" $\left(g^{\star}\right)$, where $g^{\star}$ corresponds to the weighted aggregate of the country's main trading partners (export and/or import). In this way of the external constraint manifesting itself, the participation of the NEL in world wealth can remain stable. The second way that the external restriction manifests itself is in the existence of an inflation targeting system that limits the use of the exchange rate policy (via the increase of the international reserves / gross external liabilities) and monetary policy (via the basic interest rate) to soften the external constraint.

Thirwall (1979) implicitly adopted the purchasing power parity (PPP) hypothesis (or similar) to eliminate possible real exchange rate effects over a simpler version of Thirlwall's law. However, unlike him, we preferred to maintain these variation effects over the BOP-constrained growth rate as a theoretical possibility (as in KALDOR, 1966). It seems to be the safest methodological procedure since the period covered by the intended forecast is apparently shorter than the one covered in most of Thirlwall's 
empirical analysis - and probably shorter than the usually estimated for PPP to operate, especially in Brazil-like countries. Of course, a simpler Thirlwall's law version will be virtually back if price-elasticities estimated for export and import functions are low. From these considerations, the real growth rates of sectoral exports and imports were defined by the following functions, respectively:

$$
\begin{aligned}
& x_{i, t}=\varepsilon_{i} g_{t}^{*}+\eta_{i} \hat{\theta}_{x, i, t-1} \\
& m_{i, t}=\xi_{i} g_{t}-\psi_{i} \hat{\theta}_{m, i, t-1}
\end{aligned}
$$

where $g_{t}$ is the growth rate of the domestic economy, $\hat{\theta}_{x, i}$ and $\hat{\theta}_{m, i}$ are, respectively, the variation of the real exchange rate of sectoral exports and imports; $\varepsilon_{i}, \xi_{i}, \eta_{i}$ and $\psi_{i}$ represent, in this order, the income and price elasticities of demand for sectoral exports and imports.

The maximum growth rate permitted by the balance of payments $\left(\mathrm{g}_{\mathrm{BP}}\right)$ is:

$$
g_{B P}=\frac{\left(1+g_{t}^{*}\right)\left(1+\pi_{t}^{*}\right)-\left(1+i_{M, t}^{*}+\overline{\hat{a}_{k, t}}\right)+\sum_{i=1}^{3} \chi_{i}\left[\left(1+\varepsilon_{i} g_{t}^{*}+\eta_{i} \hat{\theta}_{x, i, t-1}\right)\left(1+\pi_{x, i, t}^{*}\right)\right]+\gamma_{t}-\sum_{i=1}^{3} \mu_{i}\left[\left(1-\psi_{i} \hat{\theta}_{m i t, 1}\right)\left(1+\pi_{m i t}^{*}\right)\right]}{\sum_{n=1}^{3} \mu_{i} \xi_{i}\left(1+\pi_{m, i, t}^{*}\right)}
$$

where $\pi^{*}$ is the world inflation rate; $\mathrm{i}_{M}^{*}$ is the maintenance cost of net external liabilities (NEL) by residents; $\hat{a}_{k}$ is the moving mean of the average rate of prices change of the net external liabilities (in US\$); $\gamma_{t}$ is given by $\frac{U C T_{t}}{N E L_{t-1}}$, where UCT are unilateral current transfers; and the terms of trade are given by $\left(1+\pi_{x, i, t}^{*}\right) /\left(1+\pi_{m, i, t}^{*}\right)$, where $\pi_{x, i,}^{*}$ and $\pi_{m, i}^{*}$ are the rates of change of the prices of sectoral exports and imports (in US\$), respectively.

Besides incorporating the different income and price elasticities of exports and imports from the farming, industry and services sectors (in line with the propositions of ARAUJO and LIMA, 2007), we should highlight that according to its equation: a) a larger $g^{\star}$ increases the $g_{B P}$ not only by an increase in $x_{i}$ in a magnitude that will depend on the income elasticities of demand for sectoral exports, but also by enabling that real GDP, imports and hence the Brazilian NEL to grow faster, without however causing an explosive increase in its participation in the agents' portfolio of "the rest of the world" (according to the model proposed by LOURENÇO et al., 2011); b) the higher the ratio of sectoral exports to net external liabilities $\left(\chi_{\mathrm{i}}\right)$, the greater the $\mathrm{g}_{\mathrm{BP}}$, the inverse being verified for the ratio between sectoral imports and net external liabilities $\left(\mu_{\mathrm{i}}\right)$ (thus capturing the propositions of BHERING, 2013); and c) rather than a generic real exchange rate, the $\mathrm{g}_{\mathrm{BP}}$ depends on three different prices: the price of sectoral exports and imports and the relative prices (in constant US\$) given by the 
terms of trade of each sector, capturing in this way not only Araujo's (2011) and Ferrari, Freitas and Barbosa Filho's (2013) propositions, but also Amado and DávilaFernández's (2014) ideas. Finally, the modeling of the price formation process and of the economy's inflation was disaggregated in the farming, industry, and services sectors, according to the weight of each one in the formation of the National Extended Consumer Price Index (IPCA - Índice Nacional de Preços ao Consumidor Amplo, in Portuguese). In each period, the price formation of the aforementioned sectors depended on: i) the variation of the indirect tributary aliquot and the profit margin in the sector; ii) the variation of the wage cost of the sector; iii) the variation, in each sector $\mathrm{j}$, of the input cost produced in sector $\mathrm{i}$ and used in sector $\mathrm{j}$; and iv) the variation of the input cost imported by sector $j$. In each period, the price formation equation in each sector was defined as follows:

$$
\begin{aligned}
& \pi_{1}=P_{0,1}\left(\widehat{1+t}_{1}\right)+P_{1,1} \hat{z}_{1}+P_{2,1}\left(\widehat{W}_{1}-\hat{a}_{0,1}\right)+P_{3,1}\left(\pi_{2}-\hat{a}_{2,1}\right)+P_{4,1}\left(\pi_{3}-\hat{a}_{3,1}\right)+P_{5,1}\left(\pi_{1}-\hat{a}_{1,1}\right)+P_{6,1}\left(\hat{e}_{t}+\pi_{m, 1}^{*}-\hat{a}_{m, 1}\right)(5.1) ; \\
& \pi_{2}=P_{0,2}\left(\widehat{1+t}_{2}\right)+P_{1,2} \hat{z}_{2}+P_{2,2}\left(\widehat{W}_{2}-\hat{a}_{0,2}\right)+P_{3,2}\left(\pi_{1}-\hat{a}_{1,2}\right)+P_{4,2}\left(\pi_{3}-\hat{a}_{3,2}\right)+P_{5,2}\left(\pi_{2}-\hat{a}_{2,2}\right)+P_{6,2}\left(\hat{e}_{t}+\pi_{m, 2}^{*}-\hat{a}_{m, 2}\right)(5.2) ; \\
& \pi_{3}=P_{0,3}\left(\widehat{1+t}_{3}\right)+P_{1,3} \hat{z}_{3}+P_{2,3}\left(\widehat{W}_{3}-\hat{a}_{0,3}\right)+P_{3,3}\left(\pi_{1}-\hat{a}_{1,3}\right)+P_{4,3}\left(\pi_{2}-\hat{a}_{2,3}\right)+P_{5,3}\left(\pi_{3}-\hat{a}_{3,3}\right)+P_{6,3}\left(\hat{e}_{t}+\pi_{m, 3}^{*}-\hat{a}_{m, 3}\right)(5.3) .
\end{aligned}
$$

where $\hat{t}_{i}$ is the variation of the indirect tributary aliquot in sector $\mathrm{i} ; \hat{z}_{i}$ represents variations in the profit margin and / or the presence of other supply shocks in sector $i$; $\widehat{W}_{i}$ is the rate of change of nominal wages in sector $i$; $\hat{a}_{0, i}$ is the growth rate of labor productivity in the sector $i$; $\hat{a}_{i, j}$ is the growth rate of the productivity of domestic input use produced in sector $i$ and used in sector $j ; \hat{a}_{\mathrm{m}, \mathrm{j}}$ is the growth rate of productivity of the use of the imported input utilized in sector $j$; and $\hat{e}_{t}$ is the rate of change of the nominal exchange rate.

The variation of nominal wages $\left(\widehat{W}_{i}\right)$ was modeled as a function of the following variables: inflation of the aggregate of domestic economy $(\pi)$; rate of readjustment of the minimum wage $\left(\widehat{W}_{\text {MIN }}\right)$; unemployment rate of the economy $(\mathrm{u})$ and growth rate of labor productivity in sector $\mathrm{i}\left(\hat{a}_{0, i, t}\right)$. With regard to $\widehat{W}_{M I N}$, it is worth mentioning that it reacted to the growth of the aggregated economy with two periods of lag. With respect to $\hat{a}_{0, i, t}$, this was a direct function not only of domestic sector GDP growth (in line with the well-known Verdoorn's law), but also of real wage variation of the sector. ${ }^{1}$

With regard to the growth rate of the productivity of domestic input use produced in sector $\mathrm{i}$ and used in sector $\mathrm{j}\left(\hat{a}_{i, j}\right)$, as well as to the growth rate of productivity of the

1 See Nastepaad (2006) for a justification of the introduction of this term. 
use of the imported input used in sector $\mathrm{j}\left(\hat{a}_{m, j}\right)$ - important components of $\pi_{i}-$, they were modeled not only by making an extension of Verdoorn's law, but also by making them a function of the variation of the cost of using the inputs mentioned above. $\hat{a}_{i, j}$ was defined as the reciprocal of the technical coefficient of the input-output matrix between sectors $i$ and $j$, weighted by the respective relative price.

Finally, it should be highlighted that the growth of the domestic sectorial GDP $\left(g_{i}\right)$ were modeled so that the sum of the sectorial GDPs was equal to the country's GDP limited by :

$$
\begin{aligned}
& g_{1}=g_{0,1}+g_{1,1} g_{B P}+g_{2,1}\left(\pi_{1}-\pi_{2}\right)_{t-1}+g_{3,1}\left(\pi_{1}-\pi_{3}\right)_{t-1} \\
& g_{2}=g_{0,2}+g_{1,2} g_{B P}+g_{2,2}\left(\pi_{1}-\pi_{2}\right)_{t-1}+g_{3,2}\left(\pi_{2}-\pi_{3}\right)_{t-1} \\
& g_{3}=g_{0,3}+g_{1,3} g_{B P}+g_{2,3}\left(\pi_{1}-\pi_{3}\right)_{t-1}+g_{3,3}\left(\pi_{2}-\pi_{3}\right)_{t-1}
\end{aligned}
$$

where $g_{1, i}, g_{2, i}$ and $g_{3, i}$ are parameters and the autonomous rate of GDP growth in sector $\mathrm{i}$ $\left(g_{0, i}\right)$ was given by:

$$
g_{0, i ; t}=g_{0, i ; t-1}\left(1+\widehat{g_{0}}\right)
$$

where $\widehat{g_{0}}$ was thus defined:

$$
\begin{aligned}
& \widehat{g_{0, t}}=\left\{\left\{1+g_{B P}-\left[1+g_{1,1} g_{B P}+g_{2,1}\left(\pi_{1}-\pi_{2}\right)_{t-1}+g_{3,1}\left(\pi_{1}-\pi_{3}\right)_{t-1}\right] P_{1, t-1}-\left[1+g_{1,2} g_{B P}+\right.\right.\right. \\
& \left.g_{2,2}\left(\pi_{1}-\pi_{2}\right)_{t-1}+g_{3,2}\left(\pi_{2}-\pi_{3}\right)_{t-1}\right] P_{2, t-1}-\left[1+g_{1,2} g_{B P}+g_{2,2}\left(\pi_{1}-\pi_{2}\right)_{t-1}+\right. \\
& \left.\left.\left.g_{3,2}\left(\pi_{2}-\pi_{3}\right)_{t-1}\right] P_{3, t-1}\right\} /\left(P_{1, t-1} g_{0,1, t-1}+P_{2, t-1} g_{0,2, t-1}+P_{3, t-1} g_{0,3, t-1}\right)\right\}-1
\end{aligned}
$$

$P_{i}$ represents the weight of the aggregate nominal value of sector $\mathrm{i}$ in the total country's GDP.

Figure 1 ahead contains a scheme of the general structure of the model used in our simulations. 
Figure 1 - Simplified structure of the main determinants of the nominal exchange rate, of the $g_{B P}$, the inflation process and the growth of the domestic sectorial GDP

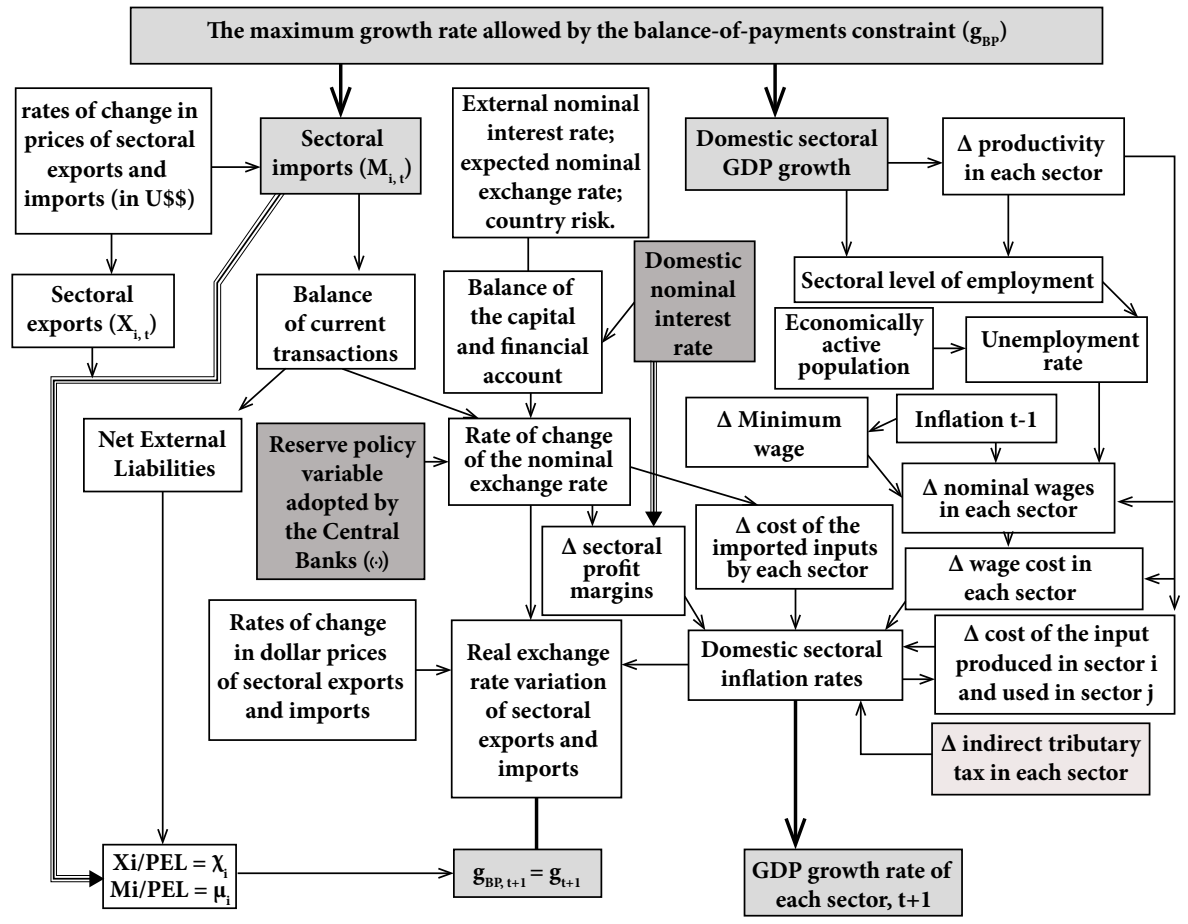

Note: $\Delta$ represents the rate of change of the variable in question.

Source: Author's own elaboration.

\section{ESTIMATION OF THE MAIN PARAMETERS OF THE MODEL IN ORDER TO DETERMINE}

\section{THE MAXIMUM GROWTH RATE PERMITTED BY THE BALANCE OF PAYMENTS}

Before directly entering into the presentation of the estimated values of the main parameters, it is convenient to start this section drawing attention to the following important aspect regarding the use of the model presented in section 1: despite the application of the moving mean of the average rate of prices change of the net external liabilities (in dollar) $-\hat{a}_{k, t}$, economic growth was still unrealistically sensitive to the high volatility typical of this financial variable; thus, in the simulations presented, we assumed $\hat{a}_{k, t}=0$. Such hypersensitivity might result from a probable direct relationship between the valuation of external liabilities and the capital flow having been relegated to future investigations. 
We are now ready to present the values of the main parameters of the model used in order to determine the $g_{B P}$, which are: the GDP growth rate of the "rest of the world" $\left(\mathrm{g}^{*}\right),{ }^{2}$ the world inflation rate $\left(\pi^{*}\right)$, the external nominal interest rate $\left(i^{*}\right)$, the income elasticities of demand for exports and imports of each sector i ( $\varepsilon_{i}$ and $\xi_{i}$, respectively), the price elasticities of demand for sectoral exports and imports $\left(\eta_{i}\right.$ and $\psi_{i}$, respectively), and the sectoral terms of trade $\left(t t_{i}\right)^{3,4}$

When we look at Table 1, it is interesting to note that all information regarding to $g^{*}$, $\pi^{*}$ and $i^{*}$ has inverted " $U$ " behavior, that is, they increase until reaching an apex in 2020, then showing a downward trajectory (2021-2025). Such behavior occurs because inflation is considered procyclical in the IMF (2015) simulations; therefore, the interest rate, under the inflation targeting regimes used by the main central banks worldwide, follows the inflation rate.

Still looking at Table 1, it is possible to notice that the terms of trade in the farming sector $\left(t t_{1}\right)$ showed a tendency of deterioration during the period 2016-2025, at the same time as the terms of trade in the industry sector $\left(t t_{2}\right)$ presented continuous appreciation. In the average of the period 2016-2025, the terms of trade of the industry sector $\left(t t_{2}=1.11\right)$ were higher than the terms of trade of the farming sector $\left(t t_{1}=0.94\right)$. Since the rates of change of the prices of services sector exports were considered equal to the rates of change of the prices of imports of the same sector, changes in the terms of trade of the services sector $\left(t t_{3}\right)$ were neutralized in the simulations presented in this article.

As regards Table 2, an important aspect that reflects the backwardness and low dynamism of the Brazilian productive structure consists in the fact that for all the income elasticities of demand for sectoral exports $\left(\varepsilon_{i}\right)$, values lower than unity were found in our estimations; on the other hand, for all income elasticities of demand for sectoral imports $\left(\xi_{i}\right)$, values higher than 2.0 were found. And since that $\xi_{2}$ and $\varepsilon_{2}$ were, in this order, the highest of all, the aforementioned results also become interesting because, in line with Kaldor's (1966) propositions also defended by Thirlwall (2013), they prove that in general, products in the industrial sector have a more dynamic

2 Where this corresponded to the weighted aggregate of the following main destinations of Brazilian exports in 2014: China, United States, European Union, and Argentina.

3 All the parametric values presented in this work are estimates obtained by the usual methods, exception for the values of $\pi^{*}$. Over the period 2014-2020, $\pi^{*}$ corresponded to projections of the International Monetary Fund (IMF, 2015) for the inflation rate of the consumer price index of the world aggregate. For the period 2021-2025, was maintained the projection of the year 2020.

4 Regarding the data series used in our simulations, in line with the National Classification of Economic Activity (CNAE 2.0 - Classificação Nacional de Atividade Econômica, in Portuguese) elaborated by IBGE (2015), the exports and imports of the industrial sector are composed of the products of the manufacturing and mining industry; and regarding the exports and imports of the farming sector, they are composed of the products of the subsectors agriculture, livestock, fishing, aquaculture, and forestry production. 
demand than the products of the farming and services sectors, thus revealing the central importance of the industrial sector to economic growth.

Regarding the price elasticities of demand for sectoral exports and imports $\left(\eta_{i}\right.$ and $\left.\psi_{i}\right)$, as can be seen in Table 2 , values equal to zero were obtained for all, except for $\psi_{3}$. Given these parametric values, exports from the farming, industry, and services sectors did not show any reaction to changes in the real exchange rate, similar to imports from the farming and industry sectors.

Table 1 - The growth rate of the "rest of the world", the world inflation rate, the external nominal interest rate, and sectoral terms of trade, 2016-2025 (in terms \%, except $\mathrm{tt}_{\mathrm{i}}$ )

\begin{tabular}{cccccccccccc}
\hline & $\mathbf{2 0 1 6}$ & $\mathbf{2 0 1 7}$ & $\mathbf{2 0 1 8}$ & $\mathbf{2 0 1 9}$ & $\mathbf{2 0 2 0}$ & $\mathbf{2 0 2 1}$ & $\mathbf{2 0 2 2}$ & $\mathbf{2 0 2 3}$ & $\mathbf{2 0 2 4}$ & $\mathbf{2 0 2 5}$ & Average \\
\hline $\mathrm{g}^{*}$ & 3.40 & 3.66 & 3.78 & 3.87 & 3.90 & 3.69 & 3.48 & 3.27 & 3.23 & 3.19 & 3.55 \\
$\pi^{*}$ & .42 & 3.56 & 3.47 & 3.50 & 3.51 & 3.51 & 3.51 & 3.51 & 3.51 & 3.51 & 3.50 \\
$\mathrm{i}^{*}$ & 1.15 & 1.47 & 1.76 & 2.18 & 2.35 & 2.33 & 2.26 & 2.27 & 2.28 & 2.29 & 2.03 \\
$\mathrm{tt}_{1}$ & 0.99 & 0.98 & 0.97 & 0.96 & 0.95 & 0.94 & 0.93 & 0.92 & 0.91 & 0.90 & 0.94 \\
$\mathrm{tt}_{2}$ & 1.02 & 1.04 & 1.06 & 1.08 & 1.10 & 1.12 & 1.15 & 1.17 & 1.19 & 1.21 & 1.11 \\
$\mathrm{tt}_{3}$ & 1.00 & 1.00 & 1.00 & 1.00 & 1.00 & 1.00 & 1.00 & 1.00 & 1.00 & 1.00 & 1.00 \\
\hline
\end{tabular}

Source: Author's elaboration based on own simulations.

Table 2 - Income and price elasticities of demand for sectoral exports and imports for the projection period, 2016/2025

\begin{tabular}{ccccccc}
\hline & $\varepsilon_{1}$ & $\varepsilon_{2}$ & $\varepsilon_{3}$ & $\xi_{1}$ & $\xi_{2}$ & $\xi_{3}$ \\
\hline $\mathbf{2 0 1 6 / 2 0 2 5}$ & 0.9163 & 0.9959 & 0.9161 & 2.1981 & 2.9059 & 2.0512 \\
\hline & $\eta_{1}$ & $\eta_{2}$ & $\eta_{3}$ & $\psi_{1}$ & $\psi_{2}$ & $\psi_{3}$ \\
\hline $2016 / 2025$ & - & - & - & - & - & -0.7464 \\
\hline
\end{tabular}

Source: Authors' elaboration based on own simulations. ${ }^{5}$

Given these results on the estimations of the price elasticities of demand for sectoral exports and imports, the projections obtained in this work for the Brazilian case did not corroborate Araujo's (2011) and Ferrari, Freitas, and Barbosa Filho's (2013) propositions. Strictly speaking, evidence from Araujo (2011) and Ferrari, Freitas, and Barbosa Filho (2013) emphasize a strong relationship between economic growth

It should be noted that such elasticities were estimated directly based on the exports and imports functions defined in the model presented in section 1 of this paper. However, in order to maintain the long-term character of the estimates, all variables were applied in terms of level and without lag. Data series used corresponded to the period 1989-2014. 
and the real exchange rate. However, according to the results of our estimations for the Brazilian's case, the aforementioned relationship was not verified when considering both the level and the variation of the real exchange rate of the sectoral exports and imports, an exception observed only in the case of the services sector, via variation of the real exchange rate of imports.

Apparently, such results are more consistent with the theoretical assumptions presented by Thirlwall (1979), who affirms that the non-price factors of competition - such as quality of goods, their technological sophistication, and modes of commercialization - are the most important to determine a country's trade performance, and thus the maximum growth rate compatible with the balance of payments. Presenting a certain consistency with Thirlwall's theoretical assumptions, it is convenient to mention the work elaborated by Lélis et al. (2017), which shows that Brazilian exports presented little sensitivity to changes in the real exchange rate over the period covered by their analysis (1995-2013).

That being said the results mentioned above suggest caution in analyzing the effects of the current model of Brazilian macroeconomic policy management on the growth of the industrial sector and the aggregate of the country's economy. Given the magnitude of the industry price elasticities estimated in this paper (see in section 3 ahead), the results suggest that the Brazilian exchange rate appreciations generate adverse effects on industrial growth and the aggregate of the economy only by indirect means, namely, through their effects on the imports of the services sector. By negatively affecting the current account balance, they end up reducing the $\mathrm{g}_{\mathrm{BP}}$ and consequently the sectorial growth rates. Bresser-Pereira and Rugitsky (2018) offer a contrary view, as they argue that the exchange rate is an instrument of a large impact on the development and growth of the industrial production structure in a long-term perspective.

\section{RESULTS OF THE SIMULATIONS: THE POTENTIAL GROWTH OF THE BRAZILIAN ECONOMY IN THE PERIOD 2016-2025}

As shown in Table 3, in the average for the period 2016-2025, the Brazilian economy showed a maximum growth rate permitted by the balance of payments $\left(g_{B P}\right)$ of only $1.32 \%$; this rate is significantly lower than the "rest of the world" average growth rate in the same period, $3.55 \%$.

Regarding the trajectory of the $g_{B P}$, the same reveal that the Brazilian economy presents a moderately more intense growth in the first years of the series (reaching an average of $2.05 \%$ in the period 2016-2020), which weakens significantly in the following years (reaching an average of only $0.60 \%$ in the period 2021-2025).

Since the "rest of the world" grows 3.72\% in the average for the period 2016-2020, which also slows to $3.37 \%$ in the average for the period 2021-2025 (see Table 1), it is 
undeniable that the aforementioned growth behavior of the Brazilian economy partly follows the growth behavior of the world economy. However, given that the deceleration of "rest of the world" growth rate in the period 2021-2025 was only 0.35 percentage points, the projections of the $g_{B P}$ also reveal a very peculiar negative aspect of the past trajectory of Brazilian growth, which is in the clearly unstable behavior of its growth, characterized by the so-called "chicken flights" (outbreaks of growth, followed by virtually "sudden stops").

When analyzing Table 3, it is still possible to realize that the low annual average of the is directly associated with the low potential growth rates of the three sectors of the economy $\left(g_{i}\right)$. In this perspective, it is interesting to note that in most of the years covering the period 2016-2025 (including the period of greatest $g_{B P}: 2017-2020$ ), the industrial sector growth rates $\left(g_{2}\right)$ were clearly below the ones of the services sector $\left(g_{3}\right)$ and the farming sector $\left(g_{1}\right)$ - in the case of comparison with this sector, exception only for the year 2017. In the average of the period 2016-2025, the industrial sector presented a growth of only $1.23 \%$, which is lower than the average of the farming $(1.31 \%)$ and services $(1.64 \%)$ sectors.

However, it is also worth noting that it is in the year which the industrial sector grows the most (2017) that the aggregate of the economy manages to obtain the highest $g_{B P}$. On the other hand, the larger $g_{1}$ and $g_{3}$ do not coincide with the year of greater $g_{B P}$; although they occur in the year (2019) which the second largest $g_{B P}$ of the series occurs, in this same year the second largest $g_{2}$ is also observed. The third and fourth largest $g_{B P}$ occur in the years when the third and fourth largest $g_{2}$ are obtained and the second and third largest $g_{1}$ and $g_{3}$ (respectively, in the years 2018 and 2020). Strictly speaking, in our simulations the behavior of $g_{2}$ directly follows the behavior of the $g_{B P^{*}}$.

Table 3 - Sectoral growth rates and of the aggregate of the economy, 2016-2025 (in \%)

\begin{tabular}{cccccccccccc}
\hline & $\mathbf{2 0 1 6}$ & $\mathbf{2 0 1 7}$ & $\mathbf{2 0 1 8}$ & $\mathbf{2 0 1 9}$ & $\mathbf{2 0 2 0}$ & $\mathbf{2 0 2 1}$ & $\mathbf{2 0 2 2}$ & $\mathbf{2 0 2 3}$ & $\mathbf{2 0 2 4}$ & $\mathbf{2 0 2 5}$ & Average \\
\hline$g_{B P}$ & 0.75 & 3.04 & 2.21 & 2.97 & 1.27 & 0.65 & 0.46 & 0.41 & 0.77 & 0.72 & 1.32 \\
$g_{1}$ & 0.69 & 2.40 & 1.93 & 2.67 & 1.32 & 0.72 & 0.67 & 0.68 & 1.03 & 1.01 & 1.31 \\
$g_{2}$ & 0.65 & 2.89 & 1.92 & 2.63 & 1.10 & 0.69 & 0.58 & 0.49 & 0.77 & 0.67 & 1.23 \\
$g_{3}$ & 1.08 & 3.75 & 3.23 & 4.14 & 1.82 & 0.56 & 0.11 & 0.14 & 0.77 & 0.85 & 1.64 \\
\hline
\end{tabular}

Source: Authors' elaboration based on own simulations.

Therefore, the results suggest that the industry sector is significant to boost growth in other sectors and, therefore, in the aggregate of the Brazilian economy. In other words, a larger growth in the industrial sector would be able to generate significant positive effects on the growth of the other sectors of the economy, not ignoring here that such positive effects occur, to some extent, due to the stronger chaining effects in 
the industry (in the sense of the pioneering approach of the economist Albert Hirschman, and also of Kaldor's approach).

Turning to the data related to Brazilian commercial transactions, Table 4 shows that sectoral exports showed a real growth trajectory $\left(x_{i}\right)$ compatible with the $g^{*}$ trajectory, growing more rapidly in the years that $g^{*}$ accelerates (2016-2020) and more slowly in the years that $g^{*}$ slows down (2021-2025). Nonetheless, given the low magnitudes of $\varepsilon_{i}$ presented in Table 2, in the average for the period 2016-2025, sectoral exports grew, in real terms, slightly below the "rest of the world" average growth (3.55\%) in the same period. It should be noted that despite the slight difference, industrial exports showed the highest average growth rate in real terms. With regard to imports, Table 4 shows that the farming and industry sectors presented a real growth trajectory of their imports compatible with the $g_{B P}$ trajectory, that is, growing more rapidly in the years in which the household economy has higher growth rates (2018-2020) and more slowly in the years of lower economic growth (2017 and 2021-2025). Imports from the services sector, on the other hand, started to grow more strongly in the years that $g_{B P}$ more strongly decelerates (2021-2025).

Once given the non-zero value obtained for the price elasticity in the services sector $\left(\psi_{3}\right)$, the abovementioned behavior of imports from this sector can be explained clearly by the strong appreciation of the exchange rate observed in the same period (see comments later regarding Table 6).

Table 4 - Real growth rates of sectoral exports and imports, 2016-2025 (in \%)

\begin{tabular}{cccccccccccc}
\hline & $\mathbf{2 0 1 6}$ & $\mathbf{2 0 1 7}$ & $\mathbf{2 0 1 8}$ & $\mathbf{2 0 1 9}$ & $\mathbf{2 0 2 0}$ & $\mathbf{2 0 2 1}$ & $\mathbf{2 0 2 2}$ & $\mathbf{2 0 2 3}$ & $\mathbf{2 0 2 4}$ & $\mathbf{2 0 2 5}$ & Average \\
\hline$x_{1}$ & 3.12 & 3.36 & 3.46 & 3.54 & 3.57 & 3.38 & 3.19 & 3.00 & 2.96 & 2.92 & 3.25 \\
$x_{2}$ & 3.39 & 3.65 & 3.76 & 3.85 & 3.88 & 3.68 & 3.47 & 3.26 & 3.21 & 3.17 & 3.53 \\
$x_{3}$ & 3.11 & 3.36 & 3.46 & 3.54 & 3.57 & 3.38 & 3.19 & 3.00 & 2.96 & 2.92 & 3.25 \\
$m_{1}$ & 1.64 & 6.69 & 4.87 & 6.52 & 2.79 & 1.43 & 1.02 & 0.89 & 1.69 & 1.59 & 2.89 \\
$m_{2}$ & 2.17 & 8.84 & 6.43 & 8.62 & 3.69 & 1.89 & 1.35 & 1.18 & 2.24 & 2.10 & 3.81 \\
$m_{3}$ & -18.53 & 8.19 & 1.85 & 5.54 & 4.13 & 5.10 & 8.75 & 7.85 & 7.96 & 6.98 & 3.46 \\
\hline
\end{tabular}

Source: Authors' elaboration based on own simulations.

Still with regard to imports, it is interesting to note that due to the high magnitudes of $\xi_{i}$ seen in Table 2, over the period 2016-2025, sectoral imports grew (in real terms) above $g_{B P}$, exception only for the service sector in the year 2016 and highlight for the industry sector in the years of greater $g_{B P}$ (2017-2019). In general, imports from the industry sector presented the fastest growing. As a result of the behaviors of $m_{2}$ and $m_{3}$, which in the 
average 2016-2025, were higher than $x_{2}$ and $x_{3}$, the deficit trajectory of the current account balance, in force since 2008 (CENTRAL BANK OF BRAZIL, 2016) remained increasing throughout the simulated period, reaching an average of US\$ 84,674.53.

Table 5 - Evolution of sectoral labor productivity, the unemployment rate in the economy and the variation of sectoral real wages, 2016-2025 (in \%)

\begin{tabular}{cccccccccccc}
\hline & $\mathbf{2 0 1 6}$ & $\mathbf{2 0 1 7}$ & $\mathbf{2 0 1 8}$ & $\mathbf{2 0 1 9}$ & $\mathbf{2 0 2 0}$ & $\mathbf{2 0 2 1}$ & $\mathbf{2 0 2 2}$ & $\mathbf{2 0 2 3}$ & $\mathbf{2 0 2 4}$ & $\mathbf{2 0 2 5}$ & Average \\
\hline$\hat{a}_{0,1}$ & 3.56 & 4.84 & 4.49 & 5.05 & 4.03 & 3.58 & 3.55 & 3.55 & 3.81 & 3.80 & 4.02 \\
$\hat{a}_{0,2}$ & -1.14 & 0.24 & -0.36 & 0.08 & -0.87 & -1.12 & -1.19 & -1.24 & -1.07 & -1.13 & -0.78 \\
$\hat{a}_{0,3}$ & -1.24 & 0.60 & 0.25 & 0.87 & -0.73 & -1.59 & -1.90 & -1.88 & -1.44 & -1.39 & -0.85 \\
$u$ & 10.34 & 9.95 & 9.58 & 8.85 & 8.48 & 8.38 & 8.31 & 8.27 & 8.08 & 7.83 & 8.81 \\
$\widehat{W}_{1}$ & 2.60 & 0.16 & 1.30 & 2.96 & 2.58 & 3.85 & 2.44 & 1.83 & 1.58 & 1.61 & 2.09 \\
$p_{1}$ & & & & & & & & & & & \\
$\widehat{W}_{2}$ & 2.05 & -0.64 & 0.50 & 1.81 & 1.99 & 3.24 & 1.88 & 1.22 & 0.84 & 0.78 & 1.36 \\
$p_{2}$ & & & & & & & & & & & -1.03 \\
$\widehat{W}_{3}$ & 0.31 & -0.44 & 0.05 & 1.05 & -0.08 & -0.20 & -1.13 & -1.34 & -1.13 & -1.02 & -0.40 \\
\hline$p_{3}$ & & & & & & & & & & & \\
\hline
\end{tabular}

Source: Authors' elaboration based on own simulations.

Suggesting the effects of Verdoorn's law, Table 5 show us that in parallel with the low growth trend of the economy, the growth of sectoral labor productivity (specially of the industry and services sectors) is slightly higher in the years when $g_{i}$ manages to grow a little higher (2017 and 2019) and lower (coming the industry and services sector even to decline) in the years when $g_{i}$ slows down $(2016,2018$, and 2020-2025). In the average of the period 2016-2025, the labor productivity in the farming sector was the one that grew the most $(4.02 \%)$. Labor productivity in the industrial and service sectors showed a decrease of $0.78 \%$ and $0.85 \%$, respectively.

Following the growth behavior of the Brazilian economy, the growth of real wages in the industry sector shows an upward trend in the period 2016-2021 and a sustained decline in their positive rates in the period 2022-2025. Similar behavior occurs in the case of real wages growth in the farming sector, which, however, shows a steady decline in its positive rates only in the period 2022-2024; in the year 2025 the growth of real wages in this sector shows a slight increase. As for the real wages growth in the services sector, there are low positive rates in the years 2016, 2018 and 2019, and significant negative rates in the years 2017 and 2020-2025. In line with the extremely low rates of labor productivity growth, it is possible to notice that the real wages of the industry sector present a growth rate of only $1,36 \%$ in the average of the period of the simulations. In relation to the services sector, real wages show an average decrease of $0.40 \%$. Already the real wages of the farming sector show an average growth of $2.09 \%$. Thus, 
it can be observed that in the average of the period 2016-2025, while real wages in the farming sector grow below $\hat{a}_{0,1}$, real wages in the industry sector grow above $\hat{a}_{0,2}$. About the services sector, the fall in real wages is lower than the reduction of $\hat{a}_{0,3}$.

The projections of the unemployment rate showed a continued downward trend even with the low Brazilian economic performance, since the weak growth of the sectoral labor productivity served as a counterpart. In the average of the period under consideration, however, there was still a high unemployment rate (8.81\%).

Finally, to model the process of price formation and sectoral inflation, the domestic interest rate (i) was calibrated exogenously in order to maintain the Brazilian inflation rate $(\pi)$ at the center of government target $(4.50 \%)$. As can be seen from Table 6 , over the entire period of simulation $\pi$ and i remain considerably higher than the world inflation rates and the external nominal interest rates shown in Table 1.

As shown in Table 6 , the inflation of the farming $\left(\pi_{1}\right)$ and industry $\left(\pi_{2}\right)$ sectors showed a trajectory with a downward trend throughout the period of simulations. Regarding the inflation of the services sector $\left(\pi_{3}\right)$, however, it had an unstable behavior, with a slight tendency of growth; this result can be directly attributed to the fact that, in comparison with the other sectors, that sector sustained the highest growth rates in the period 2016-2020 (see Table 3), which were followed by very weak growth in labor productivity throughout the period 2016-2025 (see Table 5). Therefore, in the average of the period under consideration, $\pi_{3}(5.68 \%)$ was higher than $\pi_{2}(3.91 \%)$ and $\pi_{1}(4.06 \%)$, as well as the inflation of the economy aggregate $(\pi=4.80 \%)$.

Table 6 - Sectoral and aggregate inflation rates and variables directly associated*, 2016-2025 (measured in \% terms)

\begin{tabular}{cccccccccccc}
\hline & $\mathbf{2 0 1 6}$ & $\mathbf{2 0 1 7}$ & $\mathbf{2 0 1 8}$ & $\mathbf{2 0 1 9}$ & $\mathbf{2 0 2 0}$ & $\mathbf{2 0 2 1}$ & $\mathbf{2 0 2 2}$ & $\mathbf{2 0 2 3}$ & $\mathbf{2 0 2 4}$ & $\mathbf{2 0 2 5}$ & Average \\
\hline$\pi$ & 6.50 & 5.50 & 4.50 & 4.50 & 4.50 & 4.50 & 4.50 & 4.50 & 4.50 & 4.50 & 4.80 \\
$\pi_{1}$ & 7.04 & 5.93 & 4.57 & 4.03 & 3.70 & 3.08 & 3.01 & 3.08 & 3.17 & 3.09 & 4.06 \\
$\pi_{2}$ & 5.82 & 5.85 & 4.35 & 4.21 & 3.41 & 2.73 & 2.86 & 3.08 & 3.37 & 3.44 & 3.91 \\
$\pi_{3}$ & 7.07 & 5.13 & 4.63 & 4.82 & 5.59 & 6.28 & 6.11 & 5.91 & 5.64 & 5.59 & 5.68 \\
$i$ & 15.00 & 10.00 & 8.75 & 8.50 & 8.25 & 8.00 & 7.75 & 7.50 & 7.50 & 7.50 & 8.85 \\
$e$ & 3.40 & 3.61 & 3.72 & 3.73 & 3.65 & 3.39 & 3.18 & 3.01 & 2.88 & 2.73 & 3.33 \\
$\omega$ & -0.73 & 3.59 & 2.40 & 2.49 & 2.51 & 2.41 & 2.89 & 2.67 & 2.45 & 2.20 & 2.29 \\
\hline
\end{tabular}

Note: $\left({ }^{*}\right)$ Where $\mathrm{i}$ is the basic domestic interest rate; e is the nominal exchange rate measured against the US dollar, and $\omega$ is a reserves policy variable managed at all time as a first-line instrument aiming to keep inflation at the center of the target. When $\omega>1$, it means that the country's international reserves are growing above of $\mathrm{g}^{*}$.

Source: Authors' elaboration based on own simulations.

The nominal exchange rate presented a trajectory with tendency towards appreciation; in the average of the simulation period an appreciation of $1.99 \%$ occurs. 
In this way, it is possible here to affirm that such behavior exhibited by the nominal exchange rate, by directly affecting the real exchange rate of the imports of the services sector, also contributed to obtain a low $g_{B P}$ in the average of the simulations period (2016-2025). It should be noted that in the average of the period under consideration, imports from the services sector accounted for $29.30 \%$ of total imports. The reserves policy variable of the Central Bank of Brazil $(\omega)$ was exogenously calibrated in order to maintain $\pi$ at the center of the government target (4.50\%). In this way, it should be highlighted that given the low magnitudes of $g_{B P}$ (which result in weaker inflationary pressure through faster wage growth, for example), as well as high domestic interest rates in a context where external interest rates are at low levels (a fact that facilitates the attraction of high amounts of external capital), the management of international reserves acts in the sense of releasing dollars less heavily into the market in order to appreciate the exchange rate at the exact extent necessary to put inflation at the center of the target. In the average of the period 2016-2025, $\omega$ reaches a value of 2.29 . Once this is pointed out, an interesting aspect verified in the simulations that deserves to be highlighted is that the Brazilian economy displays an implicit cycle of growth, which seems to follow four steps: $i$ ) when the $g_{B P}$ is slightly higher it allows for more robust economic growth and this tends to generate salary increases both directly (as a result of better bargaining conditions for workers in a situation of lower unemployment) and indirectly (due to the rule of minimum wage readjustment); ii) the stronger wage growth tends to generate inflation, putting into practice the mechanisms of the macroeconomic policy tripod of the Central Bank of Brazil; these, either through the basic interest rate or via the sale of international reserves, tend to generate appreciation of the exchange rate; iii) in the following years, the impact of these appreciations can be noticed on imports of services and, consequently, on the $\mathrm{g}_{\mathrm{BP}}$, decelerating it; and iv) assuming that aggregate demand growth is reduced to adjust to the deceleration of the $g_{B P}$ this, in turn, decreases, by the same pathways, the wage growth and inflation, thus allowing for greater exchange depreciation and, thus, reversing the movement of the $g_{B P}$ in the following years, and so on.

Implicit cycle of growth like to the above was also pointed out by Roos (2013, p. 130-131). For a study in line with the results found in the present paper, but more comprehensive for the case of developing countries, see Moreira (2017). According to this author, a macroeconomic policy based on an inflation target regime, primary surpluses and a floating exchange rate can create deleterious effects on economic dynamics. Taking this into account, the author suggests the implementation of an alternative macroeconomic policy based on flexible inflation targets, counter-cyclical primary surpluses and capital control without eliminating the floating exchange rate. 


\section{FINAL CONSIDERATIONS}

In view of the existence of debates that aims to explain the causes of the trend of instability and low growth of the Brazilian economy over the last decades, the present paper aimed to investigate the following question: given the current profile of the specialization pattern of the productive structure and the country's commercial insertion, as well as the current management model of Brazilian macroeconomic policy, what is the growth potential of the Brazilian economy in the period 2016-2025?

To support this study, a formal macroeconomic model oriented to projection was developed. As seen in section 1, this model was based directly on the recent theoretical developments of growth model restricted by the balance of payments, which are present in the works of Araujo and Lima (2007), Lourenço et al. (2011), Bhering (2013), Amado and Dávila-Fernández (2014), Araujo (2011), and Ferrari, Freitas, and Barbosa Filho (2013). In an attempt to make the behavior of the simulations conditioned on the current management model of Brazilian macroeconomic policy, the aforementioned model was also directly inspired by the work of Lourenço and Roos (2015).

Given the adoption of the aforementioned theoretical framework $a$ la Thirlwall (1979), it should be emphasized, therefore, that the magnitudes of the income and price elasticities of demand for sectoral exports and imports were one of the most relevant variables to explain the results obtained in this study. As seen in section 2, for all the income elasticities of demand for sectoral exports estimated, values below the unit were found; on the other hand, for all income elasticities of the demand for sectoral imports, values higher than 2.0 were found. Thus, since the income elasticities of demand for industrial imports and exports estimated were, in this order, significantly higher than the income elasticities of demand for imports and exports from the farming and services sectors, the obtained results in this work suggest that in the absence of structural transformations induced by the implementation of an efficient industrial policy in the country, the Brazilian economy will continue to present significant external constraints to its economic growth over the next few years, mainly due to the backwardness and low dynamism of its industrial sector.

As seen in section 3, in the average for the period 2016-2025, the aggregate of the Brazilian economy showed a maximum growth rate permitted by the balance of payments of only $1.32 \%$. This rate was directly accompanied by low sectoral growth rates, with the industrial sector being the lowest of all.

Revealing, however, the central importance of the industrial sector to boost Brazilian economic growth, the results obtained in this work seem to suggest that a greater growth of the industrial sector could produce expressive positive effects on the growth of the other economic sectors, not ignoring that such positive effects occur, to 
some extent, due to the stronger chaining effects in the industry. In support to this perspective, it was precisely in the year in which the industrial sector grew the most (2017) that the aggregate of the economy managed to obtain a greater $\mathrm{g}_{\mathrm{BP}}$. On the other hand, the highest growth rates of the farming and services sectors did not coincide with the year of greater $g_{B P}$; although they occurred in the year in which the second largest $\mathrm{g}_{\mathrm{BP}}$ of the series (2019) occurred, at this year the second highest rate of growth of the industry sector was also observed.

Since over the simulated period the exchange rate showed a trend of appreciation, one could imagine that the promotion of significant exchange rate depreciation is likely to generate significant positive effects on trade balance and thus on economic growth. However, given our results on the estimation of the price elasticities of demand for sectoral exports and imports (which were all nil, except $\psi_{3}$ ), the projections obtained in this work for the Brazilian case did not corroborate Araujo's (2011) and Ferrari, Freitas, and Barbosa Filho's (2013) propositions Presenting a greater approximation with Thirlwall's (1979) theoretical propositions. The real exchange rate has shown to be in our simulations a policy instrument of low effectiveness to boost Brazilian economic growth.

As seen, our results suggest that in a long-term perspective, the appreciations of the Brazilian exchange rate generate negative effects on industrial growth and the aggregate of the economy only by indirect means, which are: through its effects on imports from the services sector. These, by affecting the current account balance negatively, end up reducing the $\mathrm{g}_{\mathrm{BP}}$ and, consequently, the sectoral growth rate.

Despite what has been said about the effects of the exchange rate, according to the simulations carried out, the current management model applied to the Brazilian macroeconomic policy is an important limiting factor of the growth potential of the industry in particular and the Brazilian economy as a whole. As seen in section 3, even when the economy is able to show slightly higher growth in a period, such growth, when generating wage inflation, is immediately blocked by the macroeconomic policy mechanisms of the Central Bank of Brazil, in order to keep inflation at the center of the target. By this way, in the next period, growth weakens strongly, opening space for falling inflation and then for the resumption of growth, and so on.

Given the results obtained in this study and the weak growth of labor productivity, especially in the industry and services sectors, we conclude by highlighting not only the urgency to implement an efficient industrial policy aimed at eliminating the external structural constraints to the country's growth, but also the necessity to rethink the current model of managing the country's macroeconomic policy. Otherwise, attempts to grow in forced march will end up resulting in a type of growth characterized by the so-called "chicken flights", associated with the well-known cycles of external debt. 


\section{REFERENCES}

AMADO, A.; DÁVILA-FERNÁNDEZ, M. Conciliating Prebisch-Singer and Thirlwall: an assessment of the dynamics of terms-of-trade in a BOPC growth model. In: NATIONAL MEETING OF ECONOMICS, 42., 2014, Natal. Proceedings [...]. Niterói: ANPEC, 2014.

ARAUJO, R. A. A structural economic dynamic approach to the exchange rate: new insights from the multi-sector Thirlwall's law. Working Paper, University of Brasília, n. 347, 2011.

ARAUJO, R. A.; LIMA, G. T. A structural economic dynamics approach to balance-of-payments constrained growth. Cambridge Journal of Economics, v. 31, n. 5, p. 755-774, 2007.

AREND, M. A industrialização do Brasil ante a nova divisão internacional do trabalho. In: CALIXTRE, A. M. B.; CINTRA, M. A. M. (Eds.). Presente e futuro do desenvolvimento brasileiro. Brasília: IPEA, 2014. p. 375-421.

BHERING, G. R. F. Análise crítica dos modelos de restrição externa na abordagem Kaldor-Thirlwall. 2013. Dissertation (Master in Economics) - Institute of Economics, Federal University of Rio de Janeiro, Rio de Janeiro, 2013.

BONELLI, R.; PESSÔA, S. A. Desindustrialização no Brasil: um resumo da evidência. Texto para Discussão, IBRE-FGV, n. 7, 2010.

BONELLI, R.; PINHEIRO, A. C. Competividade e desempenho industrial: mais que só câmbio. In: NATIONAL FORUM, 24., 2012, Rio de Janeiro. Proceedings [...]. Rio de Janeiro: INAE, 2012.

BRESSER-PEREIRA, L. C.; MARCONI, N. Existe doença holandesa no Brasil? In: FORUM OF ECONOMICS, 4., 2008, São Paulo. Proceedings [...]. Rio de Janeiro: FGV, 2008.

BRESSER-PEREIRA, L. C.; RUGITSKY, F. Industrial policy and exchange rate skepticism. Cambridge Journal of Economics, v. 42, n. 3, p. 617-632, 2018.

DASGUPTA, S.; SINGH, A. Manufacturing, services and premature deindustrialization in developing countries: a Kaldorian Analysis. Research Paper 2006/049. Helsinki: UNU-WIDER, 2006.

FERRARI, M. A. R.; FREITAS, F. N. P.; BARBOSA FILHO, N. A taxa de câmbio real e a restrição externa: uma proposta de releitura com elasticidades endógenas. Revista de Economia Política, v. 33, n. 1, p. 60-81, 2013.

IBGE - INSTITUTO BRASILEIRO DE GEOGRAFIA E ESTATÍSTICA. Classificação Nacional de Atividades Econômicas (CNAE 2.0). [On-line]. IBGE, 2015. Available at: https://concla.ibge. gov.br/documentacao/documentacao-cnae-2-0.html. Accessed on: December 2015.

IBGE - INSTITUTO BRASILEIRO DE GEOGRAFIA E ESTATÍSTICA. Contas Nacionais Trimestrais: Indicadores de Volume e Valores Correntes. October - December 2017. Rio de Janeiro: IBGE, 2017.

IMF - INTERNATIONAL MONETARY FUND. World Economic Outlook Database - October 2015. By Country Groups (aggregated data) - World: Inflation, average consumer prices (2016-2020). [Online]. IMF, 2016. Available at: https://www.imf.org/en/Publications/WEO/ weo-database/2015/October. Accessed on: February 2016.

IPEADATA. Macroeconômico. Instituto Brasileiro de Geografia e Estatística / Sistema de Contas Nacionais (IBGE/SCN Anual). Indústria de transformação a preços correntes (\% PIB). 
[On-line] IPEADATA, 2014. Available at: http://www.ipeadata.gov.br/Default.aspx. Accessed on: June 2014.

KALDOR, N. Causes of the slow rate of economic growth of the United Kingdom. Cambridge: Cambridge University Press, 1966.

LÉLIS, M. T. C. et al. Economic growth and balance-of-payments constraint in Brazil: an analysis of the 1995-2013 period. EconomiA, v. 18, n. 2, p. 147-274, 2017.

LOURENÇO, A. L. C. et al. Notas sobre modelos heterodoxos de crescimento para economias abertas na linha de Kaldor e de Thirlwall. In: NATIONAL MEETING PROMOTED BY ASSOCIAÇÃO BRASILEIRA DE ESTUDOS REGIONAIS E URBANOS, 9., 2011, Natal. Proceedings [...]. São Paulo: ABER, 2011.

LOURENÇO, A. L. C.; ROOS, B. C. Efeitos do aumento da produção de petróleo sobre o potencial de crescimento da economia brasileira: um modelo voltado para a projeção (2013-2020). Estudos Econômicos, v. 45, n. 3, p. 651-681, 2015.

MOREIRA, R. R. Alternative economic policy under a regime with inflation targeting, primary surpluses and a floating exchange rate: an analysis for developing economies. European Journal of Economics and Economic Policies, v. 15, n. 1, p. 71-90, 2017.

NASTEPAAD, C. Technology, demand, and distribution: a cumulative growth model with an application to the Dutch productivity growth slowdown. Cambridge Journal of Economics, v. 30, n. 3, p. 403-434, 2006.

OREIRO, J. L.; FEIJÓ, C. A. Desindustrialização: conceituação, causas, efeitos e o caso brasileiro. Revista de Economia Política, v. 30, n. 2, p. 219-232, 2010.

PALMA, G. Quatro fontes de desindustrialização e um novo conceito de doença holandesa. In: CONFERENCE ON INDUSTRIALIZATION, DISINDUSTRIALIZATION AND DEVELOPMENT, 2005, São Paulo. Proceedings [...]. São Paulo: FIESP; IEDI, 2005.

ROOS, B. C. Economia do petróleo e desenvolvimento: estudo exploratório sobre as perspectivas do pré-sal brasileiro. 2013. Dissertation (Master in Economics) - Federal University of the Rio Grande do Norte, Natal, 2013.

THIRLWALL, A. The balance of payments constraint as an explanation of international growth rate differences. Banca Nazionale del Lavoro Quarterly Review, v. 32, n. 128, p. 45-53, 1979.

THIRLWALL, A. P. A natureza do crescimento econômico: um referencial alternativo para compreender o desempenho das nações. Brasília: IPEA, 2005.

THIRLWALL, A. Economic growth in an open developing economy: the role of structure and demand. Cheltenham: Edward Elgar Publishing, 2013. 